\title{
Front Matter: Volume 10474
}

, "Front Matter: Volume 10474," Proc. SPIE 10474, Ophthalmic Technologies XXVIII, 1047401 (4 April 2018); doi: 10.1117/12.2315715

SPIE. Event: SPIE BiOS, 2018, San Francisco, California, United States 


\section{PROGRESS IN BIOMEDICAL OPTICS AND IMAGING}

\section{Ophthalmic Technologies XXVIII}

Fabrice Manns

Per G. Söderberg

Arthur Ho

Editors

27-28 January 2018

San Francisco, California, United States

Sponsored and Published by

SPIE 
The papers in this volume were part of the technical conference cited on the cover and title page. Papers were selected and subject to review by the editors and conference program committee. Some conference presentations may not be available for publication. Additional papers and presentation recordings may be available online in the SPIE Digital Library at SPIEDigitalLibrary.org.

The papers reflect the work and thoughts of the authors and are published herein as submitted. The publisher is not responsible for the validity of the information or for any outcomes resulting from reliance thereon.

Please use the following format to cite material from these proceedings:

Author(s), "Title of Paper," in Ophthalmic Technologies XXVIII, edited by Fabrice Manns, Per G. Söderberg, Arthur Ho, Proceedings of SPIE Vol. 10474 (SPIE, Bellingham, WA, 2018) Seven-digit Article CID Number.

ISSN: 1605-7422

ISSN: 1996-756X (electronic)

ISBN: 9781510614338

ISBN: 9781510614345 (electronic)

Published by

SPIE

P.O. Box 10, Bellingham, Washington 98227-0010 USA

Telephone +1 3606763290 (Pacific Time) · Fax +1 3606471445

SPIE.org

Copyright @ 2018 , Society of Photo-Optical Instrumentation Engineers.

Copying of material in this book for internal or personal use, or for the internal or personal use of specific clients, beyond the fair use provisions granted by the U.S. Copyright Law is authorized by SPIE subject to payment of copying fees. The Transactional Reporting Service base fee for this volume is $\$ 18.00$ per article (or portion thereof), which should be paid directly to the Copyright Clearance Center (CCC), 222 Rosewood Drive, Danvers, MA 01923. Payment may also be made electronically through CCC Online at copyright.com. Other copying for republication, resale, advertising or promotion, or any form of systematic or multiple reproduction of any material in this book is prohibited except with permission in writing from the publisher. The CCC fee code is $1605-$ $7422 / 18 / \$ 18.00$.

Printed in the United States of America.

Publication of record for individual papers is online in the SPIE Digital Library.

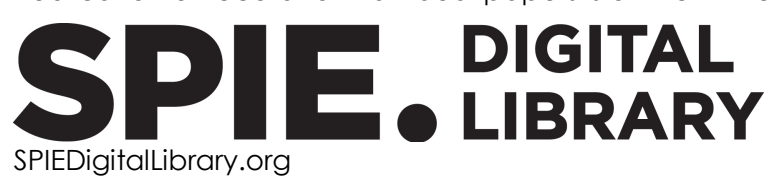

Paper Numbering: Proceedings of SPIE follow an e-First publication model. A unique citation identifier (CID) number is assigned to each article at the time of publication. Utilization of CIDs allows articles to be fully citable as soon as they are published online, and connects the same identifier to all online and print versions of the publication. SPIE uses a seven-digit CID article numbering system structured as follows:

- The first five digits correspond to the SPIE volume number.

- The last two digits indicate publication order within the volume using a Base 36 numbering system employing both numerals and letters. These two-number sets start with 00, 01, 02, 03, 04, 05, 06, 07, 08, 09, OA, OB ... 0Z, followed by 10-1Z, 20-2Z, etc. The CID Number appears on each page of the manuscript. 


\title{
Contents
}

\author{
vii Authors \\ ix Conference Committee \\ xi Introduction
}

OCULAR ANGIOGRAPHY AND PERFUSION

1047402 Multimodality optical coherence tomography and fluorescence confocal scanning laser ophthalmoscopy in a zebrafish model of retinal vascular occlusion and remodeling [10474-1]

OPHTHALMIC IMAGING: POLARIZATION

10474 OB Objective evaluation of choroidal melanin contents with polarization-sensitive optical coherence tomography [10474-10]

OPHTHALMIC IMAGING: ADAPTIVE OPTICS INSTRUMENTATION

10474 OD 3D printed phantoms of retinal photoreceptor cells for evaluating adaptive optics imaging modalities [10474-12]

OPHTHALMIC THERAPY: TREATMENT, MONITORING AND FEEDBACK

10474 ON Quantifying the effects of hydration on corneal stiffness with optical coherence elastography [10474-22]

10474 OP Toward automated selective retina treatment (SRT): an optical microbubble detection technique [10474-24]

OPHTHALMIC IMAGING: CELLULAR RESOLUTION

10474 OS In vivo imaging through the entire thickness of human cornea by full-field optical coherence tomography [10474-27]

$10474 \mathrm{OW}$ Method to investigate temporal dynamics of ganglion and other retinal cells in the living human eye (Pascal Rol Award) [10474-31] 
1047411 Anterior chamber blood cell differentiation using spectroscopic optical coherence tomography [10474-36]

OPHTHALMIC DIAGNOSTICS AND IMAGING: CLINICAL APPLICATIONS

1047413 Angular distribution of Pigment epithelium central limit-Inner limit of the retina Minimal Distance (PIMD), in the young not pathological optic nerve head imaged by OCT [10474-38]

VISUAL OPTICS AND REFRACTIVE ERROR

1047418 Evaluation of posterior porcine sclera elasticity in situ as a function of IOP [10474-43]

10474 1B Measurement and design of refractive corrections using ultrafast laser-induced intra-tissue refractive index shaping in live cats [10474-46]

\section{OPHTHALMIC MULTIMODAL IMAGING}

$10474 \mathrm{IE} \quad$ Retinal and choroidal imaging in vivo using integrated photoacoustic microscopy and optical coherence tomography [10474-49]

10474 1G Multimodality optical coherence tomography and fluorescence confocal scanning laser ophthalmoscopy for image-guided feedback of intraocular injections in mouse models [10474-51]

POSTER SESSION

$104741 \mathrm{H} \quad$ Spectral autofluorescence imaging of the retina for drusen detection [10474-52]

$1047411 \quad$ New illuminations approaches with single-use micro LEDs endoilluminators for the pars plana vitrectomy [10474-53]

$104741 \mathrm{~L} \quad$ Visual just noticeable differences [10474-56]

$104741 \mathrm{~N} \quad$ Solar exposure of sunglasses: aging test display [10474-59]

1047410 Development of a low cost UV index datalogger and comparison between UV index sensors [10474-60]

10474 1T A holographic waveguide based eye tracker [10474-65]

$104741 \mathrm{~V} \quad$ Quantitative evaluation of retinal degeneration in royal college of surgeons rats by contrast enhanced ultrahigh resolution optical coherence tomography [10474-67] 
10474 IY Quantifying changes in lens biomechanical properties due to cold cataract with optical coherence elastography [10474-70]

1047412 A new concept of imaging system: telescope windows [10474-71]

1047423 Measurement accuracy of a stressed contact lens during its relaxation period [10474-75]

1047424 Development towards compact nitrocellulose interferometric biochips for dry eye diagnosis based on MMP9, S100A6 and CST4 biomarkers using a Point-of-Care device [10474-76]

1047426 Automated classification and quantitative analysis of arterial and venous vessels in fundus images [10474-78]

1047428 Why choroid vessels appear dark in clinical OCT images [10474-80]

1047429 Retinal fundus imaging with a plenoptic sensor [10474-81]

10474 2E Corneal permeability for cement dust: prognosis for occupational safety [10474-88]

104742 Developmental approach towards high resolution optical coherence tomography for glaucoma diagnostics [10474-90]

$104742 \mathrm{H} \quad$ Accurate method for luminous transmittance and signal detection quotients measurements in sunglasses lenses [10474-91]

104742 Improved photoacoustic dosimetry for retinal laser surgery [10474-92] 
Proc. of SPIE Vol. 10474 1047401-6

Downloaded From: https://www.spiedigitallibrary.org/conference-proceedings-of-spie on 26 Apr 2023 Terms of Use: https://www.spiedigitallibrary.org/terms-of-use 


\section{Authors}

Numbers in the index correspond to the last two digits of the seven-digit citation identifier (CID) article numbering system used in Proceedings of SPIE. The first five digits reflect the volume number. Base 36 numbering is employed for the last two digits and indicates the order of articles within the volume. Numbers start with 00, 01, 02, 03, 04, 05, 06, 07, 08, 09, OA, OB...0Z, followed by 10-12, 20-2Z, etc.

Aglyamov, Salavat R., 0N, 18

Agrawal, Anant, OD

Alam, Minhaj, 26

Bashkatov, A. N., 2E

Benavides, Oscar R., $1 G$

Bergeles, Christos, 29

Bloch, Edward, 29

Boccara, Claude, OS

Bourgenot, Cyril, 12

Bozic, Ivan, 02

Brinkmann, Ralf, OP

Brooks, Daniel R., 1B

Brown, Robert B., 21

Casquel, R., 24

Chen, Minghan, $1 \mathrm{~L}$

Chen, Po-Wei, IV

Chiou, Shih-Hwa, $1 \mathrm{~V}$

Choi, Woo June, 28

Compertore, David C., 23

Courtial, Johannes, 12

Cowie, Euan, 12

Crowell, James, ow

Dalimier, Eugénie, OS

Dufour, Suzie, 21

Ellis, Jonathan D., 1B

Fink, Mathias, OS

Foubister, James J., $1 \mathrm{H}$

Gallant, Pascal, 2l

Genina, E. A., 2E

Girkin, John, 1 Z

Goh, Megan, 18

Gomes, L. M., 1N, 10, 2H

Gorman, Alistair, $1 \mathrm{H}$

Goto, Hiroshi, OB

Gregori, Giovanni, 28

Grieve, Kate, OS

Hammer, Daniel X., OD

Han, Zhaolong, ON

Harvey, Andy, $1 \mathrm{H}$

Heiduschka, Peter, $2 \mathrm{G}$

Hemert, Jano van, $1 \mathrm{H}$

Hessling, Martin, 11

Holgado, M., 24

Huang, Ziyi, $1 \mathrm{E}$

Huxlin, Krystel R., 1B

Ignatovich, Filipp V., 23

Ikuno, Yasushi, OB

Irsch, Kristina, OS

Iwasaki, Takuya, OB
Izatt, Joseph A., 11

Kalmykov, R. V., 2E

Kamenskikh, T. G., 2E

$\mathrm{Ke}$, Chang-Chih, $1 \mathrm{~V}$

Keane, Pearse A., 29

Kedia, Nikita, OD

Kemper, Björn, 2G

Ketelhut, Steffi, $2 \mathrm{G}$

Kirby, Mitchell A., 28

Knox, Wayne, 1B

Koch, Frank H. J., 11

Koelbl, Philipp Simon, 11

Kuo, Anthony N., 11

Kuo, Wen-Chuan, $1 \mathrm{~V}$

Kurokawa, Kazuhiro, ow

Laguna, María Fe, 24

Larin, Kirill V., ON, 18, 1Y

Larsen, Michael, $2 \mathrm{G}$

Lavín, A., 24

Leeburg, Kelsey C., $1 G$

Levine, Edward M., IG

Li, Chenxi, 28

$\mathrm{Li}$, Jiasong, ON

Li, Xiaoyue, 02

Lim, Jennifer I., 26

Lingenfelder, Christian, 11

Liu, Changgeng, $1 \mathrm{~T}$

Liu, Chih Hao, 18

Liu, Juan, $1 \mathrm{~T}$

Liu, Lei, $1 \mathrm{~T}$

Liu, Zhuolin, OD, OW

López-Hernandez, A., 24

López-Romero, David, 24

Loureiro, A. D., 2H

Love, Gordon, $1 \mathrm{Z}$

Maigler, M., 24

Makita, Shuichi, OB

Masili, M., $1 \mathrm{~N}$

Mazlin, Viacheslav, OS

McNabb, Ryan P., 11

Mehanathan, Sankarathi B., IG

Mermut, Ozzy, 21

Miller, Donald T., OW

Miura, Masahiro, OB

Momesso, G. A., 1N

Nair, Achuth, 18

Nankivil, Derek, $1 \mathrm{~L}$

Nguyen, Jennifer, 18

Nguyen, Van Phuc, $1 \mathrm{E}$ 
Nousias, Sotiris, 29

Ourselin, Sebastien, 29

Park, Young-Gun, OP

Paulus, Yannis M., 1E

Pazzucconi, Beatrice, $1 T$

Popova, D. V., 2E

Qian, Ruobing, 11

Raghunathan, Raksha, 18

Roh, Young-Jung, OP

Rosenfeld, Philip, 28

Sahel, José, OS

Sandberg-Melin, Camilla, 13

Santamaría, Beatriz, 24

Sanza, F. J., 24

Schnekenburger, Jürgen, 2G

Seifert, Eric, OP

Silva, F. M., IN

Singh, Manmohan, 0N, 18, 1Y

Sochol, Ryan, OD

Söderberg, Per G., 13

Son, Taeyoon, 26

Spitz, Kathleen, 02

Su, Min-Jyun, $1 \mathrm{~V}$

Syu, Jia-Pu, $1 \mathrm{~V}$

Tao, Yuankai K., 02, $1 \mathrm{G}$

Terrones, Benjamin D., IG

Theisen-Kunde, Dirk, OP

Thorn, Marie, 2G

Thurin, Brice, 29

Tian, Chao, $1 \mathrm{E}$

Toslak, Devrim, 26

Tuchin, V. V., 2E

Twa, Michael D., ON

Uematsu, Sato, OB

Vantipalli, Srilatha, $\mathrm{ON}$

Ventura, L., 1N, 1O, 2H

Wang, Ruikang, 28

Wang, Xueding, $1 \mathrm{E}$

Wooley, C. Benjamin, 1L

Wozniak, Kaitlin T., 1B

Wu, Chen, 18, 1Y

Xiao, Peng, OS

Yao, Xincheng, 1T, 26

Yasuno, Yoshiaki, OB

Young, Laura, $1 \mathrm{Z}$

Zhang, Furu, OW

Zhang, Hongqiu, IY

Zhang, Wei, $1 \mathrm{E}$ 


\title{
Conference Committee
}

\author{
Symposium Chairs
}

James G. Fujimoto, Massachusetts Institute of Technology

(United States)

R. Rox Anderson, Wellman Center for Photomedicine, Massachusetts General Hospital (United States) and Harvard Medical School (United States)

Program Track Chair

Brian Jet-Fei Wong, Beckman Laser Institute and Medical Clinic

(United States)

Conference Chairs

Fabrice Manns, University of Miami (United States)

Per G. Söderberg, Uppsala University (Sweden)

Arthur Ho, Brien Holden Vision Institute (Australia)

Conference Program Committee

Rafat R. Ansari, NASA Glenn Research Center (United States)

Michael Belkin, Tel Aviv University (Israel)

Kostadinka Bizheva, University of Waterloo (Canada)

David Borja, Alcon Laboratories, Inc. (United States)

Ralf Brinkmann, Universität zu Lübeck (Germany)

Wolfgang Drexler, Medizinische Universiteit Wien (Austria)

Sina Farsiu, Duke University (United States)

Daniel X. Hammer, U.S. Food and Drug Administration (United States)

Karen M. Joos, Vanderbilt University (United States)

Kirill V. Larin, University of Houston (United States)

Ezra Maguen, American Eye Institute (United States)

Donald T. Miller, Indiana University (United States)

Derek Nankivil, Johnson \& Johnson Vision Care, Inc. (United States)

Daniel V. Palanker, Stanford University (United States)

Jean-Marie Parel, Bascom Palmer Eye Institute (United States)

Roberto Pini, Istituto di Fisica Applicata Nello Carrara (Italy)

Ygal Rotenstreich, The Chaim Sheba Medical Center, Tel Hashomer (Israel)

Luigi Rovati, Universitá degli Studi di Modena e Reggio Emilia (Italy)

Marco Ruggeri, Bascom Palmer Eye Institute (United States)

Georg Schuele, OptiMedica Corporation (United States)

Jerry Sebag, VMR Institute (United States)

Peter Soliz, VisionQuest Biomedical, LLC (United States)

Yuankai K. Tao, Vanderbilt University (United States) 
Valery V. Tuchin, N.G. Chernyshevsky Saratov National Research State University (Russian Federation) and National Research Tomsk State University (Russian Federation) and Institute of Precision Mechanics and Control RAS (Russian Federation)

Robert J. Zawadzki, University of California, Davis (United States)

\section{Session Chairs}

1 Ocular Angiography and Perfusion

Marco Ruggeri, Bascom Palmer Eye Institute (United States)

Sina Farsiu, Duke University (United States)

2 Ophthalmic Imaging: Polarization

Donald T. Miller, Indiana University (United States)

Robert J. Zawadzki, University of California, Davis (United States)

3 Pascale Rol Lecture

Per Söderberg, Uppsala University (Sweden)

4 Ophthalmic Imaging: Adaptive Optics Instrumentation

Daniel X. Hammer, U.S. Food and Drug Administration (United States)

Derek Nankivil, Johnson \& Johnson Vision Care, Inc. (United States)

5 Ophthalmic Therapy: Treatment, Monitoring and Feedback

Ralf Brinkmann, Medizinisches Laserzentrum Lübeck $\mathrm{GmbH}$ (Germany)

Per G. Söderberg, Uppsala University (Sweden)

6 Ophthalmic Imaging: Cellular Resolution

Yuankai K. Tao, Vanderbilt University (United States)

Daniel V. Palanker, Stanford University (United States)

7 Functional Imaging and Enhanced Visualization

Wolfgang Drexler, Medizinische Universiteit Wien (Austria)

Karen M. Joos, Vanderbilt University Medical Center (United States)

8 Ophthalmic Diagnostics and Imaging: Clinical Applications

Ygal Rotenstreich, The Chaim Sheba Medical Center, Tel Hashomer (Israel)

Derek Nankivil, Johnson \& Johnson Vision Care, Inc. (United States)

9 Visual Optics and Refractive Error

Arthur Ho, Brien Holden Vision Institute (Australia)

Georg Schuele, Abbott Medical Optics (United States)

10 Ophthalmic Multimodal Imaging

Fabrice Manns, University of Miami (United States)

David Borja, Alcon Laboratories, Inc. (United States) 


\section{Introduction}

The papers contained in this volume were presented at the twenty-eighth conference on Ophthalmic Technologies, held from January 27 to 28, 2018, at the Moscone Center in San Francisco, California as a part of the SPIE Photonics West BiOS Meeting.

A total of 51 papers and 41 posters were presented by scientists, clinicians, and engineers from academia and industry representing 20 countries spanning 4 continents. Topics included new approaches using digital holography for blood flow imaging, multimodal and multispectral adaptive-optics imaging and in vivo high resolution imaging of the cornea using full-field OCT.

The conference hosted its twelfth presentation on the topic of the unmet needs and impact of technology in the clinical area. Prof. Arun Singh, from the Department of Ophthalmology at the Cleveland Clinic in Cleveland, Ohio, described the current uses of lasers for treatment of ocular tumors and the needs for better approaches.

The eighteenth Pascal Rol Award was presented to Dr. Kazuhiro Kurokawa and his colleagues from Indiana University for their outstanding paper on "Method to investigate temporal dynamics of ganglion and other retinal cells in the living human eye" (10474-31). Established in memory of Dr. Pascal O. Rol, former chair and co-founder of the Ophthalmic Technologies conference, the award is in recognition of the best manuscript and presentation. Special congratulations to Dr. Kurokawa, who also won the award in 2009, for being the first repeat winner of the award! The 2018 finalists of the award, selected by the entire program committee among 86 abstract submissions, included Theodore Dubose (1047415), Viacheslav Mazlin (10474-27), and Ruobing Qian (10474-36).

We are very grateful to Johnson and Johnson Vision for sponsoring the 2018 Pascal Rol award and keynote lecture through the Pascal Rol Foundation.

We thank the Program Committee members, session chairs, speakers and participants, as well as the SPIE staff for their support and dedication in making this conference a success.

We extend an invitation for the Ophthalmic Technologies XXIX conference, which is scheduled for Saturday February 2 and Sunday February 3, 2019 in San Francisco, CA.

\section{Fabrice Manns \\ Per G. Söderberg Arthur Ho}


Proc. of SPIE Vol. 10474 1047401-12 Downloaded From: https://www.spiedigitallibrary.org/conference-proceedings-of-spie on 26 Apr 2023
Terms of Use: https://www.spiedigitallibrary.org/terms-of-use 